\title{
Maciej Tokarski
}

Katedra Rachunkowości

Wyższa Szkoła Bankowa w Toruniu

\section{Kreatywna księgowość a fałszowanie sprawozdań finansowych}

Ostatnie kilkanaście lat bardzo zmieniło gospodarkę światową. Niewątpliwie ogromny wpływ na jej obecny kształt wywarły: postępująca globalizacja i integracja oraz pojawienie się i upowszechnienie najnowszych technologii. Procesy te bardzo zmieniły warunki funkcjonowania przedsiębiorstw, zarówno dużych (DP), jak małych i średnich (MSP).

Początek XXI w. przyniósł ujawnienie kilkunastu spektakularnych przypadków tzw. kreatywnej księgowości (m.in. Enron, WorldCom), które zachwiały zaufaniem inwestorów do rynków finansowych, w szczególności do ich przejrzystości i wiarygodności informacji. Tzw. kreatywna księgowość w połączeniu z nieuczciwością firm audytorskich spowodowała, że kwestionowane są również zasady zarządzania wartością przedsiębiorstwa mające na celu wzrost bogactwa akcjonariuszy.

Często słyszy się stwierdzenie, że polityka bilansowa jest nie tylko sztuką tego, co możliwe, lecz również sztuką tego, co jest prawem dozwolone. Świadczą o tym zjawiska określane jako: upiększanie sprawozdań finansowych, wygładzanie dochodów, finansowanie pozabilansowe czy fryzowanie sprawozdań finansowych.

Celem tego artykułu jest ukazanie - na podstawie analizy firm z gospodarki światowej oraz polskich - głównych sposobów wykorzystywania w praktyce rachunkowości kreatywnej do zarządzania przedsiębiorstwem.

\section{Pojęcie kreatywnej rachunkowości}

Na skutek licznych oszustw i upadłości holdingów i spółek w Stanach Zjednoczonych i w Europie (tab. 1) na początku XXI w. nastąpił wzrost zainteresowania jakością rachunkowości i sprawozdawczości finansowej, badaniami sprawozdań finansowych przez biegłych rewidentów oraz skutecznością kontroli i rewizji wewnętrznej.

Termin „kreatywna księgowość” nie jest nowy; jest on w powszechnym użyciu od wielu lat. Odnosi się do stosowania zasad rachunkowości w sposób, który nie jest bezpośrednio wskazany w przepisach. Nie jest to pojęcie wartościujące; nie wskazuje bezpośrednio, czy przyjęte rozwiązanie powoduje powstanie nieprawidłowości w sprawozdaniu finansowym.

Tab. 1. Przykłady firm stosujących rachunkowość kreatywną

\begin{tabular}{|l|l|}
\hline \multicolumn{1}{|c|}{ Firmy amerykańskie } & \multicolumn{1}{|c|}{ Firmy europejskie } \\
\hline Enron, WorldCom, HealthSouth, Freddie Mac, & Royal Ahold, Parmalat, Altran, Comroad, Elan, \\
Xerox, Global Crossing, HIH, Tyco, Vivendi, Adel- & Elektrim, Big Bank Gdański, Softbank, Mostostal \\
phia Communications, Merck, Qwest, Rite Aid, & Export, Rafako \\
Sunbean, Waste Management, Kmartm Peregrine & \\
Systems, Bristol Myers, Dynegy & \\
\hline
\end{tabular}

Źródło: opracowanie autora na podstawie - M. Tokarski, A. Tokarski, Rachunkowość kreatywna jako narzędzie zarządzania przedsiębiorstwem w warunkach globalizacji [w:] Mechanizmy i obszary przeobrażeń w organizacjach, A. Potocki (red.), Wyd. Difin, Warszawa 2007, s. 337. 
Często używa się określenia „kreatywna księgowość” błędnie, wyłącznie w negatywnym kontekście, podczas gdy rozwiązanie kreatywne może być pozytywne, zgodne z prawem i korzystne dla odbiorców sprawozdania finansowego. Księgowość reguluje bardzo wiele przepisów. Mają one na celu zapewnienie przedstawiania transakcji zgodnie z ich treścią ekonomiczną. Często się jednak zdarza, że operacje gospodarcze nie są uregulowane w przepisach prawa wprost. W takiej sytuacji konieczne są rozumienie intencji przepisów oraz umiejętność twórczego ich interpretowania, tak aby zaewidencjonować, a następnie zaprezentować daną operację gospodarczą zgodnie z jej rzeczywistą treścią ekonomiczną. Właściwie pojmowana kreatywność jest w rachunkowości niezbędna, przy czym powinna ona mieć granice i nie oznaczać manipulacji dokonywanych w księgach rachunkowych i sprawozdaniach finansowych (Schneider 2007, s. 232).

Bardzo istotne dla zdefiniowania kreatywnej księgowości są stwierdzenia dotyczące nieprawidłowości księgowych zawarte w Międzynarodowych Standardach Rewizji Finansowej (MSRF) nr 240, które są, a przynajmniej powinny być, swego rodzaju biblią każdego audytora. Co prawda w MSRF nie używa się pojęć „,kreatywna księgowość” i ,agresywna księgowość”, jednak występują w nich pojęcia „błąd (księgowy)” i „oszustwo (księgowe)” (Międzynarodowe Standardy Rewizji Finansowej 2001, s. 97).

Przez termin „błąd” rozumie się niezamierzone nieprawidłowości sprawozdania finansowego, łącznie z nieujęciem księgowym danych lub nieujawnieniem informacji, spowodowane np.: pomyłkami popełnionymi przy zbieraniu i przetwarzaniu danych, na podstawie których sporządza się sprawozdanie finansowe; nieprawidłowymi szacunkami księgowymi spowodowanymi przeoczeniem lub niewłaściwą interpretacją faktów; nieprawidłowym zastosowaniem zasad rachunkowości dotyczących wyceny, klasyfikacji, prezentacji lub ujawnienia informacji.

Termin „oszustwo” zaś oznacza celowe działanie podjęte przez jednego lub kilku członków kierownictwa, osoby sprawujące nadzór, pracowników lub stronę trzecią, przy wykorzystaniu kłamstwa, w celu uzyskania niesprawiedliwej lub nielegalnej korzyści.

$\mathrm{Z}$ analizy treści międzynarodowych standardów rewizji finansowej wynika, że definiują one oszustwo i błąd, wskazując na różnice intencji, jako działania umyślne (oszustwo) lub nieumyślne (błąd), które doprowadziły do powstania nieprawidłowości w badanym sprawozdaniu finansowym (Hołda, Nowak 2003, s. 117).

Według D. Krzywdy, współczesna rachunkowość wręcz wymaga od księgowych kreatywności. Kreacja w rachunkowości nie jest wynalazkiem ostatnich lat, lecz tkwi w niej od zarania. Tym większa powinna być zatem czujność audytorów, którzy nie mogą dopuścić, aby kreatywność księgowych przerodziła się w praktykę potwierdzania księgowej fikcji przez audytora (Krzywda 1999, s. 18 i 19). Według E. Mączyńskiej, należy rozróżnić pojęcia „kreatywna księgowość” i ,agresywna księgowość”. Autorka te pojęcia rozróżniła, biorąc pod uwagę różne poglądy praktyków i teoretyków rachunkowości, a także znaczenie leksykalne słów „kreatywny” i ,agresywny”. Zaproponowała ich następujące definicje (Mączyńska 2007, s. 4; Mączyńska 2002a, s. 7):

- kreatywna księgowość (rachunkowość) to prowadzenie rejestracji, ewidencji, przetwarzanie i prezentacja zdarzeń gospodarczych przy zastosowaniu obowiązujących przepisów i właściwie interpretowanych zasad rachunkowości w sposób, który nie jest bezpośrednio w tych przepisach wskazany, a który jest wynikiem pomysłowego, twórczego i niestandardowego zastosowania tych przepisów i zasad. Można ją porównać ze stosowaniem zabiegów kosmetycznych przez kobietę, która chce podkreślić swoją urodę - co przecież nie powoduje szkód dla otoczenia; 
- agresywna księgowość (rachunkowość) to świadome, zamierzone i celowe prowadzenie rejestracji, ewidencji, przetwarzanie i prezentacja zdarzeń gospodarczych w sposób sprzeczny z przepisami lub przy niewłaściwie i tendencyjnie interpretowanych przepisach oraz zasadach rachunkowości, które może zaszkodzić użytkownikom informacji księgowych przez przedstawienie innej (lepszej lub gorszej) niż rzeczywista sytuacji ekonomicznej jednostki. Jest ona prowadzona z rozmyślnym zamiarem defraudacji, ukierunkowanym na sztuczne zawyżanie zysków lub ukrywanie strat i może być bardzo szkodliwa, a w skrajnych przypadkach - co potwierdza praktyka - maskować upadłość przedsiębiorstw.

W zaproponowanej powyżej definicji agresywnej księgowości (rachunkowości) zawiera się de facto stosowane w MSRF pojęcie „oszustwo księgowe”. Zdefiniowanego przez MSRF pojęcia „błąd księgowy” w ogóle nie należy uwzględniać przy definiowaniu zarówno kreatywnej, jak i agresywnej księgowości (rachunkowości), gdyż jego istotą jest negatywne ocenianie działania niezamierzonego. Istotą zaś kreatywnej i agresywnej księgowości oraz rachunkowości jest zawsze działanie celowe i zamierzone, oceniane - w zależności od przypadku - pozytywnie lub negatywnie.

\section{Przyczyny falszowania sprawozdań finansowych}

Oszustwa księgowe nie są zjawiskiem nowym. Zdarzają się niemal od zawsze, tzn. od momentu, kiedy po raz pierwszy zestawiono majątek, dokonano jego wyceny i zaprezentowano w bilansie, ponieważ wzmiankę o tym procederze można znaleźć w dziele benedyktyńskiego zakonnika Angelo Pietra O podwójnej buchalteryi (z 1586 r.), przeznaczonego na użytek zatrudnionych w ówczesnych klasztorach. Tam też wspomniany zakonnik pisze o możliwości ,(...) dowolnych zmian w oznaczeniu wartości majątku ruchomego i nieruchomego jako środka do przedstawienia ostatecznego bilansu w świetle dodatnim albo ujemnym, lecz bynajmniej nie prawdziwym" (Dutlinger 1912, s. 5). Oznacza to, że księgowy powinien nie tylko zmierzać do sumiennego i uczciwego prowadzenia ksiagg, lecz także posiąść umiejętność właściwego prezentowania sprawozdań finansowych. Już w 1912 r. pisano, że ,(...) bycie księgowym to nie tylko umiejętność księgowania i znajomość podstawowych zasad rachunkowości. Trzeba również umieć czytać pomiędzy wierszami. Nie dość zgodzić debet z kredytem, trzeba twórczo kontrolować i badać. Za mało jeszcze dokładnie zaksięgować, dodać odpowiednie pozycje. Należy znać interes i ludzi, czuć liczby, być artystą, a nie zwykłym rzemieślnikiem" (Dutlinger 1912, s. 7). Te stwierdzenia są nadal aktualne. Należy nie tylko księgować, lecz także interpretować, prowadzić politykę bilansową, która pozwoli kreować właściwy, pożądany obraz sytuacji gospodarczej jednostki, a ona jest możliwa jedynie wówczas, gdy istnieje wybór konwencji i zasad przy sporządzaniu dokumentu, jakim jest sprawozdanie finansowe. Dążenie do przedstawienia firmy we właściwym świetle doprowadziło do wypracowania wielu metod ,upiększania” danych w sprawozdaniach finansowych przy wykorzystaniu luk w regulacjach prawnych lub nawet działań na granicy prawa. Jedne z tych metod mogą mieć charakter nadużyć, czyli być fałszerstwami, co czyni je nagannymi, inne zaś są bliższe sztuce umiejętnego ,upiększania”, co czyni je dopuszczalnymi, a określane jest także mianem polityki bilansowej (Cebrowska, Jeżowski 2000, s. 4).

Oszustwa księgowe nie są zjawiskiem nowym, nigdy jednak nie stanowiły takiego zagrożenia dla stabilności światowego systemu finansowego jak obecnie, co wynika z postępującej liberalizacji przepływu kapitałów i siły roboczej między różnymi regionami i krajami, wskutek czego wzrósł stopień niepewności odnośnie do przetrwania na rynku w warunkach zaostrzającej się konkurencji i gwałtownych zmian zachodzących we wszystkich sferach życia społecznego i gospodarczego (Kutera, Hołda, Surdykowska 2006, s. 9). 
Często słyszy się stwierdzenie, że polityka bilansowa jest nie tylko sztuką tego co możliwe, lecz również sztuką tego, co jest prawem dozwolone. Świadczą o tym zjawiska określane jako: twórcza księgowość, upiększanie sprawozdań finansowych, wygładzanie dochodów, finansowanie pozabilansowe, maskowanie bilansu, strojenie okna wystawowego, rasowanie czy fryzowanie sprawozdań. Terminy te dotyczą kreowania rachunkowości i sprawozdań finansowych przez zarząd w celu poprawienia obrazu działania i sytuacji firmy nie zawsze zgodnie z prawem. W związku z tym pojawia się problem celu i zakresu kreowania polegającego na manipulacji zasadami rachunkowości, aby stworzyć wrażenie, że sytuacja finansowa firmy jest inna niż w rzeczywistości.

Ustalając przyczyny fałszowania sprawozdań finansowych, trzeba uwzględnić następujące kwestie:

1. To chciwość pompuje powietrze w balony dobrej koniunktury, to chciwość winduje w górę wartość akcji, wartość firmy, i każe sobie tłumaczyć wzrost rzekomo posiadanym kapitałem intelektualnym, to przez chciwość są ustalane nieprzyzwoicie wysokie wynagrodzenia kadry menedżerskiej skorelowane najczęściej niesłusznie z wysoką wartością firmy, to chciwość w końcu powoduje, że balony przegrzanej koniunktury pękają z hukiem, który słychać w całej globalnej wiosce (Sojak 2003/2004, s. 168).

2. Naturę człowieka i jego niczym nieskrępowaną kreatywność, w której mieści się brak etyki zawodowej, konflikt lojalności, chciwość i egoizm, brak skrupułów i elementarnego poczucia odpowiedzialności.

3. Od postrzegania przedsiębiorstwa przez podmioty zewnętrzne zależy możliwość jego dalszego rozwoju. Sprawozdanie finansowe staje się więc wizytówką firmy, sposobem prezentacji na zewnątrz wyników jej działalności. Wiele firm stara się o to, aby ich sprawozdania finansowe wyglądały jak najlepiej i aby osoba czytająca je miała jak najlepsze wrażenie o firmie.

4. W miarę komplikowania się procesów gospodarczych posiadanie informacji stało się kartą przetargową między właścicielem a zarządem. Następowała coraz większa sprzeczność interesów. Typowy jest stan, kiedy zarząd ma więcej informacji niż właściciel. Dysponent informacji (zarząd) może je wykorzystać w sposób zabezpieczający jego własny interes, nawet przy stratach właściciela (Kamela-Sowińska 2003, s. 3).

5. Warunkiem sprzyjającym rachunkowości kreatywnej w negatywnym tego słowa znaczeniu jest presja sprostania oczekiwaniom rynku lub wymaganiom właścicieli i wierzycieli (red. Świderska 2006). Ogłaszanie wyników znacznie niższych od oczekiwanych może spowodować wycofanie się obecnych inwestorów lub wstrzymanie napływu nowych. Ponadto, jeżeli spółka w danym roku wykaże wyjątkowo dobre wyniki, to powstanie presja, by w kolejnych latach były one równie wysokie. Presja inwestorów i wierzycieli może być wystarczająco silna, by zarząd uległ pokusie kształtowania danych.

6. Przyczyną przekroczenia cienkiej granicy pomiędzy rachunkowością mającą rzetelnie prezentować efekty ekonomiczne a fałszowaniem sprawozdań finansowych mogą być także osobiste korzyści kadry kierowniczej, jeśli przyznawane im nagrody zależą od krótkookresowych wyników spółki.

7. Możliwości wykorzystania dostępnych zasad rachunkowości jest wiele. Często podstawą ich przyjęcia jest szacunek, np. utrata wartości składników aktywów, albo subiektywne założenie, np. wybór metod amortyzacji czy wycena rozchodu zapasów.

8. Globalizacja rynków, która stawia firmom ogromne wyzwanie organizacyjne. Bardzo skomplikowane wielopoziomowe struktury holdingowe, składające się z wielu spółek zależnych rozrzuconych po całym świecie, działających w różnych branżach i formach prawnych, stają się coraz mniej przejrzyste i zrozumiałe, są więc coraz wygodniejszą platformą manipulacji. 
Fałszowanie sprawozdań finansowych może dotyczyć wszystkich obszarów wykazywanych w bilansie i rachunku zysków i strat, przy czym z analizy funkcjonowania firm stosujących rachunkowość kreatywną wynika, że najczęściej są to (Wiśniewska 2006, s. 47 i 48):

- zawyżenie wyniku finansowego przez nietworzenie odpisów aktualizujących składniki majatkowe,

- wykorzystywanie odroczonego podatku dochodowego do kreowania wyniku,

- zaniżanie wyniku poprzez kwalifikowanie do kosztów wydatków o charakterze inwestycyjnym,

- nieprawidłowa wycena aktywów i pasywów oraz instrumentów finansowych,

- kwalifikowanie przychodów do rozliczeń międzyokresowych przychodów,

- nieprawidłowa kwalifikacja przychodów na przełomie roku,

- przesunięcia kosztów pomiędzy latami sprawozdawczymi,

- nietworzenie rezerw na grożące jednostce straty i ryzyko,

- nieuzasadniona przecena majątku,

- błędna kwalifikacja kosztów,

- nieprawidłowe ujęcie transakcji w czasie,

- nienaliczanie odsetek od zobowiązań i należności,

- nieprawidłowa ewidencja,

- nieprawidłowa prezentacja w sprawozdaniu finansowym,

- nieprawidłowe odpisy amortyzacyjne,

- nieprawidłowa wycena produkcji w toku,

- brak kompletności kosztów i przychodów,

- brak inwentaryzacji należności,

- niezgodne dane dotyczące prawa wieczystego użytkowania gruntów,

- nieaktualna dokumentacja inwestycyjna,

- nieprawidłowe ustalenie dochodu podatkowego,

- nieprawidłowy podział na długo- $\mathrm{i}$ krótkoterminowe aktywa i pasywa,

- brak inwentaryzacji aktywów i pasywów drogą weryfikacji danych,

- inne zasady w Zakładowym Planie Kont niż stosowane w praktyce,

- nieuzgadnianie rozrachunków na podstawie uzgodnień sald,

- wyprowadzanie kapitałów ('środków finansowych),

- nierzetelność spisów z natury rzeczowego majątku obrotowego,

- brak kontroli wewnętrznej lub jej złe funkcjonowanie,

- zawyżanie aktywów,

- zawyżanie kapitałów,

- nietworzenie rezerw na świadczenia pracownicze,

- manipulowanie wynikiem,

- brak wykazywania zmian zasad (polityki) rachunkowości,

- wykazywanie fikcyjnych nierozliczonych zaliczek,

- zmiany zasad wyceny z roku na rok,

- odcięcia czasowe,

- błędy w rozliczaniu kontraktów długoterminowych,

- błędy dotyczące ujęcia i wyceny instrumentów finansowych,

- wprowadzanie kosztów niedotyczących danej działalności,

- błędy lub brak udokumentowania operacji gospodarczych,

- nieprawidłowe udokumentowanie operacji gospodarczych,

- fikcyjne zapisy księgowe, 
- zaliczanie do przychodów niewykonanych usług lub niesprzedanych wyrobów w związku z realizowanymi fikcyjnymi transakcjami (wystawiane są faktury, ale produkt nie opuszcza zakładu, a po upływie pewnego czasu wystawiane są faktury korygujące),

- fałszowanie sprawozdań finansowych,

- błędy w stosowaniu prawa podatkowego,

- nieprzestrzeganie zasady ostrożności,

- brak prawidłowej kwalifikacji dotacji,

- błędy w szacowaniu rezerw na zobowiązania,

- sterowanie przychodami poprzez mieszanie metody kasowej z memoriałowa,

- brak wyceny bilansowej,

- brak odpisów aktualizujących na należności o małym prawdopodobieństwie zapłaty,

- uznawanie za odrębne środki trwałe urządzeń, które nie spełniają samodzielnych funkcji użytkowych, ale są elementami środka trwałego (dyski komputerów; drukarki),

- błędna kwalifikacja umów leasingowych,

- podawanie należności i zobowiązań per saldo,

- wykazywanie należności krótkoterminowych jako długoterminowych w celu uzyskania niższych wskaźników rotacji,

- kompensowanie należności ze zobowiązaniami bez podstawy prawnej i ustaleń umownych,

- brak zasad (polityki) rachunkowości,

- utrzymywanie należności nieściagalnych, umownych, przedawnionych i wykazywanie ich w aktywach.

\section{Podsumowanie}

Wskutek postępu globalizacji powstają globalne standardy rachunkowości. Zaskakująco szybko rośnie liczba połączeń przedsiębiorstw, coraz częściej następuje integracja rynków kapitałowych, i to nie tylko w ramach Unii Europejskiej. Przepływom kapitału między różnymi krajami i regionami świata towarzyszy nieodłączne ryzyko inwestowania. Na skutek konieczności uzyskania odpowiedniej efektywności rynków kapitałowych wyłoniła się potrzeba funkcjonowania wysokiej jakości informacji finansowej, co z założenia może zapewnić jedynie zastosowanie jednolitych zasad rachunkowości. Nowoczesna rachunkowość musi być jakościowo lepsza od tradycyjnej, choć ustalenie kryterium jej oceny nie jest proste. Na szczególną uwagę zasługuje znaczenie praktyki. Następuje daleko idąca intelektualizacja rachunkowości, która polega na tym, że praktycy w rachunkowości muszą się posługiwać interdyscyplinarną wiedzą o przedsiębiorstwie, a więc znajomością kodeksu spółek handlowych i kodeksu cywilnego, procedur postępowania cywilnego i administracyjnego, prawa podatkowego i pochodnych tego prawa, znajomością systemów informacyjnych i informatycznych oraz rozległą wiedzą z dziedziny rachunkowości.

Rola biegłego rewidenta w systemie społeczno-gospodarczym wiąże się ściśle z rolą, jaką odgrywa w nim rachunkowość. Informacje wychodzące z systemu rachunkowości powinny służyć podejmowaniu racjonalnych decyzji gospodarczych zarówno wewnątrz przedsiębiorstwa, jak i przez zewnętrznych jego użytkowników. Na jakość tych informacji mają wpływ zarówno osoby tworzące te informacje, jak i osoby dokonujące ich weryfikacji - biegli rewidenci. Ujawnienie istotnej, kompletnej i wiarygodnej informacji w sprawozdawczości finansowej, na podstawie której użytkownicy tego sprawozdania mogą podejmować właściwe decyzje ekonomiczne, zależy od tego, w jaki sposób osoby zajmujące się rachunkowością będą stosować istniejące prawo oraz dorobek teorii i praktyki rachunkowości. 
Najprawdopodobniej trzeba będzie pogodzić się z brakiem w pełni skutecznych rozwiązań przeciwdziałających manipulacjom księgowym. Dlatego podstawową funkcją standardów i innych regulacji rachunkowości powinno być dostarczenie wystarczającej pewności, że system księgowości nie wymknie się spod kontroli. Powinny one umożliwiać m.in. wczesne rozpoznanie zagrożeń dla działalności i przypadków stosowania rachunkowości agresywnej oraz tworzenie systemu wczesnego ostrzegania inwestorów. Rozstrzygająca jest jednak etyka menedżerów, księgowych, audytorów i członków rad nadzorczych. Stąd też przy ich doborze istotne jest staranne uwzględnianie nie tylko kwalifikacji zawodowych, ale i predyspozycji osobowościowych. Niestety, o osobowości w biznesie niełatwo. Trawestując znaną sentencję Konfucjusza: „W państwie rządzonym dobrze wstyd być biednym. W państwie rządzonym źle wstyd być bogatym”, można ją w pełni odnieść do rachunkowości. Jeśli jest agresywna - zyski zasługują nie na pochwałę, lecz na naganę.

We współczesnej rachunkowości nie wystarczą dobre prawo i dobre rozwiązania techniczne. Równie ważna jak profesjonalizm osób zajmujących się rachunkowościąjest ich postawa etyczna. W gąszczu coraz bardziej komplikującej się działalności gospodarczej istnieje ogromne zapotrzebowanie na tworzenie zasad i wskazówek postępowania w sytuacjach trudnych dla poszczególnych grup zawodowych. Coraz większa grupa osób widzi więc potrzebę tworzenia tego typu zasad w formie kodeksów etycznych. Rachunkowość to nie tylko prawo, teoretyczne i praktyczne zasady, to również postawa etyczna osób, które się nią zajmują.

\section{Literatura}

1. Cebrowska T., Jeżowski M., Fatszowanie i fryzowanie bilansów-nieco historii, „Problemy rachunkowości”, $1 / 2000$.

2. Dutlinger J., Fałszywe bilanse, Nakład Biblioteki Handlowej w Warszawie, Warszawa 1912.

3. Hołda A., Nowak W., Oszustwa w systemie rachunkowości a ewolucja procedur badania sprawozdań finansowych, „Zeszyty Teoretyczne Rachunkowości”, t. 13(69), Warszawa 2003.

4. Kamela-Sowińska A., Ską się wzięła sprawa ,Enronu”, „Rachunkowość”, 4/2003.

5. Krzywda D., Rachunkowość finansowa, FRR w Polsce, Warszawa 1999.

6. Kutera M., Hołda A., Surdykowska S., Oszustwa księgowe - teoria i praktyka, Wyd. Difin, Warszawa 2006.

7. Mączyńska E., 2002a, Nie twórcza, tylko agresywna, „Gazeta Prawna”, nr 219/2002.

8. Mączyńska E., Białe plamy i pułapki dzisiejszej rachunkowości, „Rachunkowość”, 9/2007.

9. Mechanizmy i obszary przeobrażeń w organizacjach, A. Potocki (red.), Wyd. Difin, Warszawa 2007.

10. Międzynarodowe Standardy Rewizji Finansowej, Standard nr 240: Odpowiedzialność biegłego rewidenta za uwzględnianie podczas badania sprawozdania finansowego możliwości wystapienia oszustw ibłędów.

11. Schneider K., Btędy i oszustwa w dokumentach finansowo-księgowych, PWE, Warszawa 2007.

12. Sojak S., Kreatywna rachunkowość - fatszerstwo czy pomyst na wyższy zysk?, „Roczniki Naukowe Wyższej Szkoły Bankowej w Toruniu", J. Wiśniewski (red.), nr 3(3) 2003/2004, Wyd. WSB w Poznaniu.

13. Sprawozdanie finansowe bez tajemnic, G.K. Świderska (red.), Wyd. Difin, Warszawa 2006.

14. Wiśniewska J., Przestrzeganie etyki w praktyce rachunkowości w ocenie biegłych rewidentów, „Problemy rachunkowości”, kwiecień-czerwiec 2006. 


\section{Creative Accountancy - Embezzlement of Financial Statements}

The balance policy is not the art of what is possible but also the art of what is permissible by the law. Testify about these occurrences qualified as: creative accounting, window dressing, incomes smoothing or off balance sheet financing. The aim of article is to present the main factors of creative accounting - based on the examples of analyses many firms from the world and Polish companies - as an instrument of management in the company. 